\title{
Metasomatism of Cratonic Lithosphere by Hydrous, Silica-rich, Fluids Derived from Recycled Sediment: Experimental Insights at 5-7 GPa
}

\author{
R. P. Rapp, S. Timmerman, J. Lowczak and A.L. Jaques \\ The Australian National University, Canberra, Australia, robert.rapp@anu.edu.au, \\ suzette.timmerman@anu.edu.au,jessica.lowczak@anu.edu.au,lynton.jaques@anu.edua.u
}

\section{Introduction}

It is generally accepted that diamond formation in the sub-cratonic lithospheric mantle (SCLM) was associated with the influx of solute-rich, mixed C-O-H fluids (Shirey et al., 2013) that also acted as transformative metasomatic agents, chemically re-fertilizing the SCLM, and representing an important part of cratonic stabilization in the Archean. Understanding the nature and origin of these fluids and how they might have interacted with the lithospheric mantle is therefore a crucial part of models for both craton evolution and diamond genesis. Terrigenous crustal material (e.g., "continental sediment") that has been "recycled" in some manner into the base of a developing cratonic root during continent formation could serve as an important source of such fluids. The high-density fluid' microinclusions (HDFs) found in fibrous diamonds provide some constraints on the composition of these fluids, although they may not be directly relevant to metasomatism of the oldest SCLM (Shirey et al., 2013). Mineral inclusions in gem diamonds, presumably syngenetic with their hosts (Stachel and Harris, 2008), also provide clues to how these fluids may have interacted with the depleted peridotite residues of melting (Walter, 1999) that comprised the cratonic root or "keel" of the Archean lithospheric mantle. Where did these fluids originate, how did their influx affect the chemical composition and mineralogy of the SCLM, and what role did they play in diamond formation?

\section{Experimental Approach}

The idea that fluids derived from tectonically-recycled "continental" sediments are important to both diamond formation and metasomatism of the SCLM has been explored through a series of laboratory experiments in the multi-anvil apparatus at pressures of 5-7 GPa and $\sim 900-1200^{\circ} \mathrm{C}$. Multi-capsule experiments allow us to simultaneously (1) determine the geochemical characteristics of "pristine" fluids derived from water- and carbonate-bearing "terrigenous" metasediments, representing recycled crustal material in the SCLM, through phase equilibria experiments on natural sediment starting materials, and (2) observe how such fluids react with and chemically enrich surrounding peridotite, through fluid 'infiltration-and-metasomatism' experiments in which a crustal fluid source ("sediment") is overlain by a layer of peridotite ("lithospheric mantle"). Fluids produced in the first type of experiment can be directly assessed as diamond-forming fluids, given that they form under P$\mathrm{T}$ conditions appropriate to the diamond stability field $\left(900-1200^{\circ} \mathrm{C}, 5-7 \mathrm{GPa}\right)$, along a typical cratonic geotherm $\left(32-37 \mathrm{~mW} / \mathrm{m}^{2}\right)$. And the compositions of metasomatic minerals produced by reaction between these same crustal fluids and mantle peridotite in the second type of experiment can be directly compared with those of the same phases occurring as presumably 'syngenetic' inclusions in diamonds. The terrigeneous sediment component in the first type of experiments is represented by (1) a water-rich, carbonate-poor starting material (MAG-1 USGS marine mud), (2) a carbonate-rich, water-poor starting material from the western Alps (Saas-Fee metapelite, SFMP), and (3) a third starting material comprised of a 1:1 mechanical mixture of the first two. A peridotite from the Kamchatkan sub-arc mantle represents the depleted Archean SCLM in the second type of experiment.

\section{Composition of sediment-derived fluids and comparison with HDF inclusions in diamonds}

The amount of fluid produced in the phase-equilibria experiments ranges from $\sim 10 \%$ to more than $50 \%$ by volume, depending upon the bulk composition and temperature. Fluids derived from water- 
rich terrigenous sediments at 5-7 GPa are in equilibrium with a kyanite eclogite (gt+cpx+kyanite) phase assemblage that also contains phengite, $\left(\mathrm{Fe}-\mathrm{Ni}\right.$ ) sulfide and coesite below $\sim 1050^{\circ} \mathrm{C}$; co-existing fluids contain between 20 and $40 \mathrm{wt} \%$ mixed $\mathrm{H}_{2} \mathrm{O}-\mathrm{CO}_{2}$ component, possess high $\mathrm{K}_{2} \mathrm{O} / \mathrm{Na}_{2} \mathrm{O}(>10)$, are high in normative quartz and orthoclase and are peralkaline $(\mathrm{Na}+\mathrm{K}>\mathrm{Al})$. When compared with high-density fluids (HDFs) found in fibrous diamonds, the experimental fluids from the water-rich sediment source show a striking similarity, both in compositional range and major-element chemistry, to the hydrous silicic end-member calculated by Klein-Ben David et al (2009) for Yakutian diamonds, the calculated and measured compositions of HDF inclusions in fibrous diamonds from Congo (Navon et al, 1988; Schrauder and Navon, 1994), and to the fluid composition measured in diamond Z4 from Zaire (Navon et al, 1988) as one specific example that is particularly well correlated with the experimental results. The compositions of "pristine" sediment-derived fluids produced in our experiments are plotted in terms of molar $(\mathrm{K}+\mathrm{Na}),(\mathrm{Si}+\mathrm{Al})$ and $(\mathrm{Ca}+\mathrm{Fe}+\mathrm{Mg})$ components on Figure 1, where they are compared with HDFs in fibrous diamonds from a number of localities worldwide.

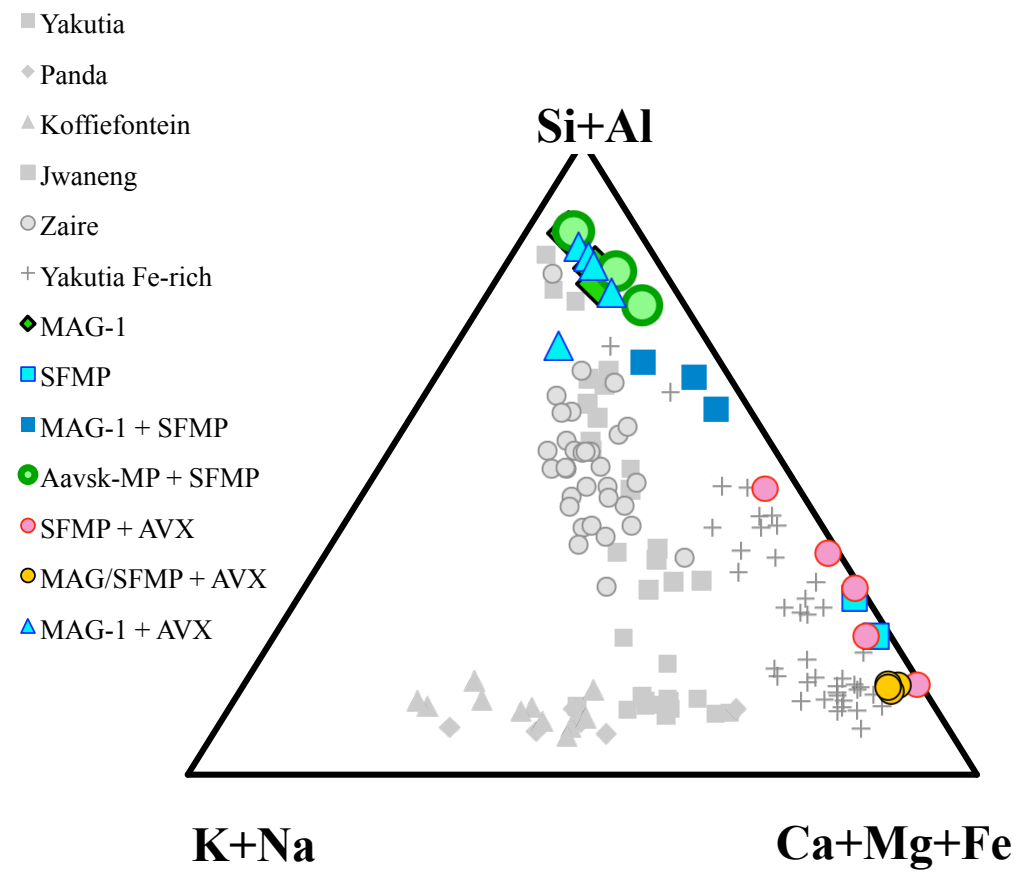

Figure 1. Ternary diagram of $\mathrm{K}+\mathrm{Na}, \mathrm{Si}+\mathrm{Al}$, and $\mathrm{Ca}+\mathrm{Mg}+\mathrm{Fe}$ showing the composition of "pristine", sedimentderived fluids produced in experiments with: water-rich pelite (MAG-1), carbonate-rich pelite (SFMP), and 1:1 mixes of carbonate-rich and water-rich pelite (MAG-1+SFMP) and carbonate-rich and water-poor pelite (AaskMP+ SFMP). Shown relative to compositions of high density fluid inclusions in diamonds from Yakutia (Klein-BenDavid et al., 2009), Panda (Tomlinson et al., 2006), Koffiefontein (Izraeli et al., 2001, 2004), Jwaneng (Schrauder and Navon, 1994), Zaire (Navon et al., 1988; Kopylova et al., 2010), and Yakutia (Fe-rich compositions; Zedgenizov et al., 2009). Also shown for comparison are mantle-hybridized fluids formed by reaction between pristine, sediment-derived fluids and depleted peridotite AVX.

The effect of the initial reaction between the hydrous fluids derived from water-rich sediments and the overlying peridotite layer in the "infiltration-and-metasomatic reaction" experiments is to consume most of the fluid in metasomatic reactions of the form:

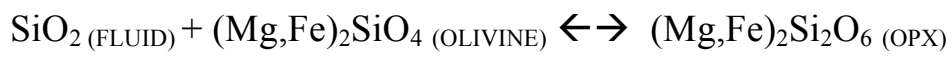

that increase modal orthopyroxene at the expense of (consumed) olivine, dramatically reducing the amount of $\mathrm{SiO}_{2}$ in the fluid whilst also enriching the "residual" fluids in $\mathrm{K}_{2} \mathrm{O}$ (up to $20 \mathrm{wt} \%$ ) and $\mathrm{Cl}$ 
(up to $14 \mathrm{wt} \%$ ). This is manifested in the peridotite as a relatively narrow zone of modal metasomatism, characterized by an orthopyroxene-rich reaction front, beyond the sediment-peridotite interface, that also contains Na-amphibole and phlogopite at lower temperatures $\left(\leq 1000^{\circ} \mathrm{C}\right)$. Beyond this lies a region of more "cryptic" metasomatism, marked by isolated pockets of residual (saline?) fluids, highly enriched in $\mathrm{K}$ and $\mathrm{Cl}$ components concentrated from the original fluid. This implies that continued reaction between hydrous, $\mathrm{SiO}_{2}$-rich crustal fluids and peridotitic mantle will drive residual fluids from silicic towards increasingly more carbonatitic/saline compositions. Klein-BenDavid et al (2009) observed that decreasing Si (65 to $10 \mathrm{wt} \%)$ and $\mathrm{Al}$ (13 to $2 \mathrm{wt} \%)$ contents in HDFs in fibrous diamonds from Yakutia, Russia were correlated with an increase in $\mathrm{K}$ (10 to $22 \mathrm{wt} \%)$ and $\mathrm{Cl}(0.7$ to 3 $\mathrm{wt} \%$ ), similar to the trends observed in our experiments.

The ubiquitous presence of Cr-rich, Ca-poor (G-10) garnets in depleted peridotite that has been infiltrated, reacted with, and metasomatized by hydrous, sediment-derived silicic fluids in the secondtype of experiment is an important manifestation of the type of reactions that would take place between sediment-derived fluids and cratonic peridotite, and strongly suggests that such water- and silica-rich crustal fluids play a key role in both the chemical evolution of the SCLM, and the origin of diamonds.

\section{References}

Izraeli, E.S., Harris, J.W. and O. Navon (2001) Brine inclusions in diamonds: a new upper mantle fluid. Earth Planet. Sci. Lett. 187, 323-443.

Izraeli, E.S., Harris, J.W. and O. Navon (2004) Fluid and mineral inclusions in cloudy diamonds from Koffiefontein, South Africa. Geochim. Cosmochim. Acta 68, 2561-2575

Klein-BenDavid, O. Izraeli, E.S., Hauri, E. and O. Navon (2007) Fluid inclusions in diamonds from the Diavik mine, Canada and the evolution of diamond-forming fluids. Geochim. Cosmochim. Acta 71, 723-744.

Kopylova, M., Navon, O., Dubrovinsky, L., and G. Khatchatryan (2010) Carbonatitic mineralogy of natural diamond-forming fluids. Earth Planet. Sci. Lett. 291, 126-137.

Navon, O., Hutcheon, I.D., Rossman, G.R. and G.J. Wasserburg (1988) Mantle-derived fluids in diamond micro-inclusions. Nature 335, 784-789.

Schrauder, M. and O. Navon (1994) Hydrous and carbonatitic mantle fluids in fibrous diamonds from Jwaneng, Botswana. Geochim. Cosmochim. Acta 58, 761-771.

Shirey, S.B., Cartigny, P., Frost, D.J., Keshav, S., Nestola, F., Nimis, P., Pearson, D.G. and M.J. Walter (2013) Diamonds and the geology of mantle carbon. Reviews in Mineralogy \& Geochemistry Vol. 75 pp. 355-421.

Stachel,. T. and J.W. Harris (2008) The origin of cratonic diamonds - Constraints from mineral inclusions. Ore Geology Reviews 34, 5-32.

Tomlinson, E.L., Jones, A.P. and J.W. Harris (2006) Co-existing fluid and silicate inclusions in mantle diamond. Earth Planet. Sci. Lett. 250, 481-595.

Walter, M. J. (1999), Melting residues of fertile peridotite and the origin of cratonic lithosphere, in Mantle Petrology: Field Observations and High-Pressure Experimentation: A Tribute to Francis R. (Joe) Boyd, edited by Y. Fei, C. M. Bertka, and B. O. Mysen, Spec. Publ. Geochem. Soc., 6, 225239.

Zedgenizov, D.A., Ragozin, A.L, Shatsky, V.S., Araujo, D., Griffin, W.L., Kagi, H., 2009. Mg and Fe-rich carbonate-silicate high-density fluids in cuboid diamonds from the Internationalnaya kimberlite pipe (Yakutia). Lithos 112 (Supplement 2), 638-647. 